\title{
Therapeutic Work With Victims of Sexual Violence in War and Postwar: A Discourse Analysis of Bosnian Experiences
}

\author{
Inger Skjelsbæk \\ International Peace Research Institute, Oslo (PRIO) and \\ Institute for East European and Eurasian Studies (ISEEES) \\ at the University of California, Berkeley
}

\begin{abstract}
This article presents a discourse analysis of 23 interviews with local Bosnian health workers at 2 different psychosocial centers. The main premise for the study is based on the acknowledgment that many victims of war rape will choose to remain silent about their ordeals, and studies of this particular war phenomenon must therefore be based, in part, on other local voices in the field. The main focus is on the ways in which the health workers describe their work with victims of sexual violence in the Bosnian war and postwar settings. Through their descriptions we gain unique insight into how the issue of war rape was addressed and dealt with at a local level. Further, on a general level, the study shows that the impact of sexual violence in war varies according to context, an insight that has implications not only for our general understanding of the phenomenon, but also in the use of particular therapy methods. These therapy methods must balance between the assumptions that there are universal effects of sexual violence that cut across various contexts and cultural relativism that assumes the opposite.
\end{abstract}

Rape is an integral, yet often unnoticed, part of warfare. During the final days of World War II, for instance, between 110,000 and 900,000 German women were raped by Russian forces (Seifert, 1994). Further, 20,000 Chinese women are thought to have been raped in Nanking following the Japanese takeover of the city in 1937 (Seifert, 1994). The "numbers game" in the former Yugoslavia indicates

Correspondence should be sent to Inger Skjelsbæk, International Peace Research Institute, Oslo (PRIO), Hausmanns Gate 7, N-0186, Oslo, Norway. E-mail: inger@ prio.no 
that somewhere between 10,000 and 60,000 women of various ethnic groups may have been raped (Bernard, 1994; Jones, 1994; Jordan, 1995; "Rape as a Weapon," 1993; Stiglmayer, 1994; Thomas \& Ralph, 1994). In Rwanda, it is believed that between 250,000 and 500,000 women, predominantly Tutsis, were raped (Human Rights Watch, 1996). Despite these high numbers, there are remarkably few studies about this particular war phenomenon. One prime reason for this lack of knowledge is the victims' silence about their ordeal. This silence was broken with the Bosnian war, during which we learned about the systematic use of rape as the events were taking place. Not only was this openness new, but it also meant that we had access to information about these acts of violence at a much earlier stage than in previous conflicts. Understanding the Bosnian experience is therefore critical to broaden our knowledge about this war phenomenon.

For the sake of argument, let us assume that (a) the impact of sexual violence in the Bosnian war is not known, (b) the victims of sexual violence in war most likely will remain silent about their sufferings, and (c) the truth about sexual violence cannot be attained because most research methods will be inadequate. Let us also assume that despite these difficulties we have ethical and pragmatic reasons for studying sexual violence in war. How, then, can the research community study this war phenomenon? Which data, that is, whose voices, can enlighten us? Which methods can be used and which theories can help us to understand what we see?

\section{VOICES}

One central premise of this article is that the victims of sexual violence will most likely not talk about their experiences. To analyze the impact of this particular violence, research must therefore rely, at least in part, on other voices. The following pages focus on how local health workers ${ }^{1}$ describe their work, and themselves, in relation to victims of sexual violence in both war and postwar Bosnia.

Acts of sexual violence perpetrated against women in Bosnia-Herzegovina during the war of 1992-1995 received unprecedented attention in the media and among politicians and aid workers. This massive focus led to the establishment of numerous organizations aimed at helping the victims of this particular form of violence in the region. Women's nongovernmental organizations (NGOs), which provide social and legal help as well as psychosocial centers, are now scattered throughout Bosnia providing a network of expertise on both war and postwar

\footnotetext{
${ }^{1}$ The term health worker has been used in this article to encompass the vast array of different backgrounds of the interviewees in this study. This approach means that the cook, the nurse, the theologian, the pedagogue, and the psychologist (to name just a few professional groups) are all included in the term health worker, because they all have been trained in various ways to meet and talk to severely traumatized people. Despite their different tasks, they all share a therapeutic function vis-á-vis the clients.
} 
trauma. These health workers are among the few who have talked - and still talkdirectly and regularly with victims of this particular form of violence, and they therefore have unique insights into how such violence has affected the victims, their families, and their communities. Further, these health workers act as links between victims of sexual violence and the Bosnian community at large. They not only work with the individual victims themselves, but they also do outreach work in their respective communities by directing attention to the situation of women in Bosnia and by making their work known to a larger public. In both of these contexts, the health workers have had to overcome taboos that make speaking about sexual violence a particularly difficult task.

\section{RESEARCH QUESTIONS}

This article will focus on the following research questions:

1. What interpretive repertoires are applied when the health workers describe their work with victims of war rape?

2. What interpretive repertoires are applied when the health workers describe their work with victims of war rape vis-á-vis their work with victims of postwar rape?

\section{SEXUAL VIOLENCE DISCOURSES}

In this article, I start from the premise that the meaning, understanding, and reality of sexual violence in war is shaped through discourse (Gergen, 1999; Jørgensen \& Phillips, 1999; Wetherell, 2001). Social constructionist scholarship suggests that the researcher focus the discourse analysis on interpretive repertoires made available through talk, descriptions, and other manifestations of a given phenomenon. According to Potter and Wetherell (1987), an interpretive repertoire is "basically a lexicon or register of terms and metaphors drawn upon to characterize and evaluate actions and events" (p. 138). In other words, the aim of this analysis is to explain which statements, identities, and modes of practice are made possible within different discourses on sexual violence. Therefore, it is important to analyze sexual violence not only in the context of war, but also in the context of how this phenomenon is contrasted with sexual violence in a postconflict setting.

The ways in which sexual violence is conceptualized in the interviews with the health workers bring out two distinct yet highly interrelated discourses of violence against women. On the one hand, sexual violence is framed as war violence and is thereby assigned to a specific time period (the war between 1992 and 1995), altered material life conditions (threat of killings and destruction of homes and prop- 
erties), and an aberrant set of morals and values (ethnic cleansing). Sexual violence in this context is contrasted with what is seen as postwar violence. This form of violence is euphemistically called domestic violence and is located within families and linked to patriarchal value structures. In the two main subsections that follow, we will see how interpretive repertoires and identities are constructed within discourses of war violence and postwar violence, respectively. However, before going deeper into the analysis itself, a few words on methodology are necessary.

\section{METHOD}

No all-encompassing methodology for the study of sexual violence in war can be defined. The researcher must approach the analysis of data from the perspective that the findings are one among many plausible avenues toward an understanding of the phenomenon under study.

\section{Interviews and Participants}

The primary data on which this article is based consist of 23 core interviews with health workers from two different psychosocial centers in Bosnia. Despite great diversity in their backgrounds, there are certain characteristics that unite these health workers. They all describe their initial interest in doing this work as a result of feeling paralyzed by the political situation in the early war years. The people who got together were colleagues, friends, and neighbors, and, consequently, it was a close-knit network that they established. The health workers were all women, and their ethnic background was predominantly Bosniak2: $78 \%$ of the interviewees were Bosniak, $13 \%$ were of mixed Croat-Serb background, $4.5 \%$ were of CroatBosniak background, and $4.5 \%$ were of Croat background. They ranged in age from 25 to 63 years. The interviews were conducted at the two psychosocial centers. In one case, I lived at the center for the week I was there, whereas, in the other case, I stayed at a nearby hotel and visited the center each day of my stay.

These interviews are part of a larger study focusing on how the rapes during the Bosnian war affected gender relations and perceptions of gender violence in the aftermath of that conflict. The total number of interviews in the larger study was 55 .

\footnotetext{
${ }^{2}$ The term Bosniak has a long history in Bosnia and has been used both as a generic term for inhabitants of Bosnia (Bošnjak) and as a term for Muslims living in Bosnia at different points in time (for an elaborate discussion, see Bringa, 1995, pp. 34-36). In present day Bosnia, however, according to Ronelle Alexander, Professor of Slavic Languages and Literatures at the University of California (UC), Berkeley, the term Bosniak has replaced the religious identifier Muslim. Thus, Bosniak now denotes Muslims in Bosnia, whereas the term Bosnian denotes inhabitants of Bosnia of different nationalities (Ronelle Alexander, presentation at the conference "The Muslim World in Eastern Europe," UC, Berkeley, April 26-27, 2003).
} 
The 23 core interviews on which this article is based were with health workers who worked full time at the two psychosocial centers. Their daily contact with women victims of violence set them apart from the other interviewees in the larger study. In addition to these 23 health workers, 17 interviews were with other professionals at medical centers, as well as lawyers, peace negotiators, members of the international community in Bosnia, and NGO workers, whereas 16 interviews were with women who received help as a consequence of different war traumas such as rape, torture, and the loss of family members in a massacre; finally, 6 interviews were with focus groups (in Sarajevo, Banja Luka, and Mostar). In addition, I was an observer at two therapy sessions at a "collective center" (a euphemism for a refugee settlement) for internally displaced persons (IDPs).

The full set of interviews was carried out over the course of five field trips between September 2001 and June 2002. The interviews, which lasted for approximately $1 \frac{1}{2} \mathrm{hr}$ each, were all recorded and transcribed by me. The result has been close to 800 pages of transcribed text, of which the 23 interviews at issue here constitute but one part. In addition to these texts, personal observations, informal conversations, field notes, and observation of the physical reality in which the health workers find themselves are important factors in establishing the context from which the discourse analysis can emerge.

All interviews were semistructured and followed an interview guide. Within this guide, a number of core themes were considered particularly important: the health workers' own accounts of the startup of the center and their involvement in that process, descriptions of their work, their perceptions of working in an allwoman environment, their perceptions of the change of focus from war traumas to postwar traumas, their thoughts on how the local community regarded the psychosocial centers, and their thoughts about and hopes for the future of the center.

With a single exception, all of the interviews were carried out with one of three local interpreters, all of whom were women. The decision against using the Bosnian language in the interviews was based not only on my very limited knowledge of the language, but also on the recognition that the theme of study could be so sensitive that it was likely to be very difficult for me to master nuances and distinctions regarding sexual violence and other kinds of war trauma. ${ }^{3}$

When I returned from the field to start analyzing my data, I was uncertain as to what kind of text the transcribed interviews actually represented. The text was inevitably the product of three different voices: the interviewer, the interviewee, and the interpreter. Little has been written about the methodological challenges within discourse analysis, and this is especially true for analyses within foreign language settings. Because the voices of the interviewees and the interpreters are blurred in the transcribed text, this indistinction forces an analysis with a broad focus. A

\footnotetext{
${ }^{3}$ More detailed information about the intricacies of interviews under such conditions is available from the author.
} 
close reading of word selections, phrases, or pauses in the language will be difficult because it is not entirely clear whose words and voices are reflected in the transcribed text. Nevertheless, the text can be considered a manifestation of how meanings and implications of sexual violence are constructed by the health workers, in cooperation with the interpreters in the postconflict Bosnian setting. Within these discourses the health workers speak from different subject positions: as victims of war, as professional health workers, as liaisons between the rape victims and their local communities, and as women. The interpreters reconstruct the health workers' accounts by selecting words and references within the English language, which, in turn, bring the knowledge, experiences, and perceptions of the health workers out to a larger international audience.

\section{DISCOURSES OF WAR VIOLENCE}

Women's sexuality was not a theme for open debate in the Socialist Federal Republic of Yugoslavia or in Bosnia. This does not mean that there was no recognition that acts of sexual violence took place, but rather that these were perceived as being private problems, not an area of public concern. A useful illustration can be found in Gal and Kligman (2000, pp. 96-97), in which the authors described how the response to the opening of an SOS Hotline in Belgrade in the late 1980s radically changed the public discourse on violence against women. It came to be perceived as a social problem, that is, something that could be of public concern rather than an exclusive part of married life.

To the health workers' knowledge, there were no such hotlines before the war, and therefore, no public discourse on the issue of sexual violence against women in prewar Bosnia. During the war years, however, sexual violence became a public theme as well as a tool in the political conflict. Not only was a public discussion about rape something new in the Bosnian context, it also represented a shift in the ways in which weapons of war were perceived and defined on the international level. The notion of sexual violence as a weapon of war is prevalent among researchers and journalists writing about the Bosnian war (see Allen, 1996; Bernard, 1994; Jordan, 1995; Vranic, 1996). In Salzman (1998), the systematization of the use of sexual violence is even given a name: the RAM plan (p. 356), which was drafted by the Psychological Operations Department within the Yugoslav National Army in August 1991. According to this plan, raping women and even children would help crush the Muslim population's morale and desire for battle. The United Nations envoy to Bosnia from 1993 to 1995, Thorvald Stoltenberg, provided another example. He said that at almost all of the meetings he had with the leaders of the various warring parties (Slobodan Milosevic, Alija Izedbegovic, and Franjo Tudjman), accusations would be thrown back and forth about the numbers of 
women that soldiers from the different sides had raped (personal communication, February 7, 2002).

For the health workers in Bosnia, the challenge was how to deal with this violence in a therapeutic setting when they had no previous experience with this particular form of violence and no therapeutic language through which to address it. Somehow, the issue of sexual violence needed to be made explicit and recognized as a unique form of violence that should be given as much attention as possible during the war and to find ways of helping its victims. What the health workers did was to situate themselves both as victims of war, thereby focusing on having shared experiences with their clients, and as professional therapists, thereby focusing on being different from their clients. In addition, discourses of survival and shame were central themes in the health workers accounts, and in the following we will see how these themes are framed.

\section{Discourses of Victimization}

Despite their difference in age, education, and working history, many of the health workers found common ground in their descriptions of how they became involved in and motivated about working with women victims of violence. They were all victims of the war. One health worker explains how she perceived the situation:

We all lived with trauma in our families, fear of dying. If it was not from the shelling, then we were afraid to die from hunger. For almost 2 years, we were in the middle of a blockade, and we could not get anything from the outside. It is only now that I understand how traumatizing this was for us.

They describe victimization as loss of mobility, physical and emotional security, and a predictable future. For the health workers, the war meant a sharp decline in their standards of living, and this aspect of their victimization was hurtful and humiliating. One health worker described how she had to clean other people's houses to make ends meet after having been accustomed to having help at home herself. She polished her nails at night so that no one would see how worn her hands were. Another health worker described how she used her fur coat, a symbol of her former wealth and status, to fetch wood for her stove, which had replaced the electric oven they could no longer use. However, this form of victimization was described as being very different from the ordeals that the clients had gone through. The majority of the health workers lived in their own homes during the war. They were urban and educated, whereas their clients were predominantly rural and in many cases uneducated. Despite these differences, situating themselves as victims created a sense of unity between the health workers and the clients and was a prime motivation for initiating psychosocial work. It was the recognition that they were 
all victims in different ways that gave the health workers the added energy they needed for the kind of work they did.

The first meetings with IDPs-many of whom had been raped, lost their homes, and seen family members killed-were difficult, but rewarding, as this woman explains:

Working with women at that time and at that stage made it easier for me to cope with myself and my life in a better way, if you can understand what I mean. Another thing was that I was happy to be of help.... I was afraid that something might happen because it was the war, but seeing what the women had been through and they were still alive gave me the message that I will have the strength to go through whatever I have to go through, and I will live because if they do, I will as well.

Another health worker confirmed how the psychosocial work was a source of comfort, stability, and solidarity throughout the war years and in the aftermath of the conflict:

Very often I would feel support from the therapy group members who had numerous losses in their families. In addition to all their suffering, they managed to offer me their help, and the therapy sessions were therefore a mutual exchange of experiences, and that was very good.

\section{Discourses of Professionalism}

The recognition of shared victimization was, according to the health workers, important in motivating them for this particular kind of work. However, it was also important to create a distance between themselves and their clients to avoid getting burnt out. The health workers had to become professionals in dealing with war traumas. At the beginning of their work, the mere naming of sexual violence appeared as a major obstacle for the health workers, because they were then forced to make visible a "private" matter within a public (albeit confidential) space (the psychosocial center). The challenge was to acquire an appropriate language and appropriate therapy methods to deal with this issue. One health worker described this insecurity in her account of the first group of clients she had, of which several were rape victims:

I was silent and a little closed in myself and a little bit inhibited, and I was just looking at them. I could not see them so well because there were just candles [the electricity was out], but this field officer asked them questions about what had happened to them. I was afraid that I would hurt them if I asked them too many questions. In this first group of clients, we did not use 
the word rape at all: they talked about when IT happened, and we asked questions about how and when IT happened, and we always talked about IT. And we tried to do some relaxation exercises, but we were all so tense: they were tense, and we were tense, and there was shelling, and sometimes the shelling interrupted the groups and we had to go into the basement and stop the therapy.

As this quote suggests, the issue of sexual violence was perceived as so taboo that it was difficult even to name it. Another health worker handled the issue by avoiding conversations with clients who would bring out the theme. Her solution was to sing when she was on night shifts:

In the beginning, I was afraid to start talking to them about the things that had happened to them, because I was not sure that I would be able to cope with it. So, you know, there were nights when we were singing all night. I am the last person to sing in public, but I would rather sing than have one or two or three start talking about painful issues. So I decided it was better to sing rather than have such messy questions and messy topics that I did not know what to do with.

The way the health workers coped with their own insecurities was through education. Before the formal opening of the centers, ${ }^{4}$ health workers were able to find scholarly literature in related fields in either German or English. One or two people would read these texts and translate them for the others, and through this approach, highly eclectic therapeutic models could be modified to fit the needs of their clients.

Midway through the war, the health workers came in contact with internationals who were willing and eager to fund and support local initiatives aimed at helping women raped during the war. It was these contacts that led to the formal establishment of the two psychosocial centers. These contacts also led to an array of courses and seminars offered to the health workers. Sometimes the educators came to them, and sometimes the health workers traveled abroad. However, few, if any, of the seminars and courses fitted the situation in Bosnia at the time, as the following quote suggests:

Everything we learned in those seminars [organized by internationals] and from the literature [Western psychology] we had to remodify because we worked in very specific conditions, and the issue of rape was a topic we had

\footnotetext{
${ }^{4}$ For further details on setting up the centers, see the Appendix.
} 
not faced before ... and perhaps even we as therapists saw it as a kind of shame of the woman it happened to.

Most courses were organized by Western Europeans or Americans. The educators had no direct experience with sexual violence during war but used their expertise and experiences from other conflicts and trauma theory. The themes covered stretched from the Vietnam War syndrome and torture methods used in Chile to trauma education related to natural disasters and even traffic accidents. As the above quote suggests, the challenge for the international educators was not only to try to fit existing theories on sexual violence, trauma, and therapy to the extreme situation of the Bosnian war, but also to help the health workers overcome their inhibitions and inexperience in talking and dealing with the issue of sexual violence. For the health workers, on the other hand, there was a need to point out that the war in Bosnia was remarkably gruesome and the acts of sexual violence were such that it was difficult for even the most ardent psychiatric professional to find an appropriate way to respond:

You could be the best psychologist in Europe, but when it comes to war trauma you become a little toy student.

The previous statement could have indicated that the education they received was useless, but in fact, the health workers express considerable appreciation and eagerness to learn. The basis for such attitudes was twofold. First, the education they received made them better qualified to deal with the traumas of their clients, increasing their level of professionalism and their identity as professionals. It also served as a way of legitimizing their own intuitive - and often pre-education-responses to the clients, as the following statement illustrates:

I was wondering if my tears were helpful or damaging. Maybe I should not do what I was doing? And I had my doubts about my behavior and my empathy in that process. And later on I met a Dutch woman who helped me get rid of those doubts, and she said that sort of behavior had nothing to do with my knowledge but was part of my response.

Second, as a side-effect, the education provided them with a way of coping and understanding the distress, uncertainty, and pain they had all gone through during the war, and therefore served as a sort of self-help.

The identities the health workers developed as professionals in dealing with war traumas rested on how they contrasted their knowledge and experiences with those of their clients and educators. The education provided them with a language and therapeutic tools to address war traumas, sexuality, and violence vis-á-vis their clients. In other words, by adopting a therapeutic language and learning therapeutic 
tools, they became better equipped to handle the traumas of their clients, which, in turn, gave them increased authority and responsibility. Yet, at the same time, the health workers were the experts on local perceptions and taboos regarding sexual violence. This meant that they acted as professionals in transforming scholarly knowledge and therapeutic tools related to war trauma to fit the context of the Bosnian war. It was the health workers who knew how to best balance outside knowledge (i.e., Western psychology) with inside (i.e., Bosnian) cultural taboos. One example of such balancing was the use of a female Muslim theologian and health worker at one of the centers. She made religious visits to women who otherwise might not have been allowed by their families to receive help from a psychosocial center. By making religious visits, the theologian was able to reach these women and talk about war traumas in a nonthreatening way and without creating problems for the women in their families.

\section{Discourses of Survival}

The health workers consistently and insistently refused to describe their clients as victims, referring to them instead as "war-rape survivors" or "war trauma survivors." When I asked why they used the word "survivor" rather than the more common word "victim," they replied that they did not wish to victimize the women further and that "survivor" evokes a more positive, stronger image than "victim."

By insisting on using "survivor," the health workers evoked the image of a fighting soldier, an image most often associated with men. This use of imagery was further affirmed and brought into the public discourse by the imam ${ }^{5}$ in Sarajevo, who issued a fatwa 6 in 1994 in which he declared that Bosniak women who had been subjected to sexual violence ought to be looked on as war heroes, that is, viewed in the same way as soldiers. One of the health workers explained:

The Islamic Association-at that time most of our clients were Muslim women-issued a proclamation that women who were raped in the war should have the position of a soldier, of a fighter, you know. They were seen like equals, almost like war heroes who got killed, although these women did not get killed. The religious association said it was not by their will; they were misused for war purposes by the enemy. This religious approach changed the attitude of a lot of men, and they got a better understanding for what happened to their wives.

Among the health workers I spoke to both in Bosnia and abroad (I also interviewed three Norwegian and two German health workers), this fatwa was men-

\footnotetext{
${ }^{5}$ The man who leads prayer in a mosque; authority on Islamic theology and law and spiritual leader.

${ }^{6}$ Ruling on a point in Islamic law that is given by a recognized authority.
} 
tioned as being very important. The experiences of the raped women were conceptualized on the same level as those of soldiers involved in the fighting. The fact that the religious leaders openly addressed the rape issue, and characterized the rape victims as war heroes, may have shifted the way in which the raped women were received and perceived within many families. One result was that the war-rape victims were often protected by their families rather than being ostracized. One health worker provided an example:

Sometimes the husband would come to the center and say that strange and brutal things had happened to his wife. And because some men had the experience of being in prison or in concentration camps, they were aware of the things that were going on there and they had an understanding of what their wives were going through.

This scenario suggests that the husband knew what had happened to his wife and wanted her to get help, which is in contrast to the common perception that a raped woman would be so stigmatized that she would be left by her husband or bring shame on her family (Allen, 1996; Brownmiller, 1994; Card, 1996; MacKinnon, 1994; Seifert, 1994 ). It is unclear how common this reaction was. However, for the health workers, the imam's engagement and public condemnation of the perpetrators created a possibility for a new understanding of the victims and could have positive implications for victim-family relations.

The discourse of survival brings out a new identity construction for the clients at the psychosocial centers. They are cast as ethnic survivors in a context in which different ethnicities are allocated innocence and guilt in a politicized manner. The discourse of ethnicity is the most prevalent one in the scholarly and political analyses of the Bosnian war. Ethnicity was seen as the prime reason for the conflict, ${ }^{7}$ as well as a key factor in finding a peaceful resolution to the fighting. The division of Bosnia today into a Serb Republic and a Croat-Bosniak Federation stands as testimony to how successful the discourse of ethnicity was and continues to be. The health workers are careful to point out, however, that they do not reserve their help for women of only one particular ethnicity. Both of the psychosocial centers are in principle multiethnic. Yet, casting the clients within ethnic boundaries creates a good base for therapy—both men and women were attacked, albeit in different

\footnotetext{
${ }^{7}$ In his memoirs of his role as peace negotiator in the Bosnian conflict, Richard Holbrooke (1999) described what he called "the Rebecca West Factor": Rebecca West (1942/1977) wrote the first English-language book about the Balkan region in which she is overtly pro-Serb and anti-Muslim. In addition, Robert Kaplan's (1993) book, Balkan Ghosts: A Journey Through History, echoed some of the thoughts of Rebecca West and influenced policymakers to think that the conflict in the region was based on age-old hatred between ethnic groups. It also convinced many-especially U.S. politicians and U.S. President Bill Clinton in particular-that nothing could be done about the bloodshed (Holbrooke, 1999).
} 
ways, because they belong to the same ethnic group. The violated body of the Bosniak victim of sexual violence "belongs" to her ethnic group, and through these experiences the entire ethnic group is perceived as being attacked.

The combination of gender and ethnicity has become so powerful within writings on the Bosnian war that the image of the raped victim is the image of a Bosniak woman abused by a Serb male perpetrator, wrote Zarkov (1997). Other victim-perpetrator constellations have been overshadowed, which has hit Serb victims particularly hard, not only in Bosnia but also in the international media. For the Serb population, the survivor image of the rape victim might therefore have been a more difficult image to evoke, because the Serbian ethnicity has been conceptualized as the identity of the perpetrator. Mixed identities complicate this discourse even further, although this was not a theme in our interviews - most likely because the majority of the clients were Bosniak.

\section{Discourses of Stigmatization}

Although the Muslim leaders in Bosnia, through the fatwa described previously, lifted some of the stigma normally attached to victims of sexual violence, the threat of stigmatization remained throughout the war years. The health workers had to deal with this threat in different ways. They emphasized the importance of creating a safe environment for their clients. They thought it would be easier for victims of sexual violence to come to the centers if they had an all-female profile. However, in adopting such an approach, it was important to make sure that the centers did not become know as "rape centers," because a "rape center would have no clients," as one health worker pointed out. It would simply be too stigmatizing for the victims to approach such a center. They portrayed the centers as places where women with different war traumas could receive help, underscored by one health worker who explained that "all our clients were women with war traumas, physical and psychological." If the clients' reasons for coming to the center were multifaceted, then the help the centers offered needed to be equally diverse. One of the health workers at Center A explained:

We did several things to make the whole procedure easier. First of all, our services were always free of charge for our clients. Second, all the employees and professionals were women ... and the center was able to cover all segments of their need like accommodation, clothes, psychological assistance, etc.

At Center A, there was an additional reason for emphasizing treatment of different kinds of war experiences: the structure of the building in which the center was located. The waiting room at the front of the building had a glass door through which passersby could get a glimpse of the clients. If passersby knew that the cen- 
ter treated women with different war traumas, it was not possible for them to know exactly why any one particular client was there.

Although Center A emphasized the positive sides of describing sexual violence as one of several war traumas that women victims of war suffered from, interviews with health workers at Center B revealed how this contextualization could also be problematic. They argued that describing sexual violence as one of several war traumas becomes a way of hiding — and thereby maintaining — the stigma attached to victims of sexual violence. They make extensive use of group therapy, and within such groups, everything that is said is confidential and does not leave the room. Still, the health workers at Center B explained that only rarely have they had cases where a client openly admitted to having been subjected to sexual violence. The alternative of having specific groups for victims of sexual violence, however, is ruled out as impossible:

It would never have been possible to form a [therapy] group of women who had that kind of trauma [rape], but it happened that amongst the groups' members there were women who had that experience, but very rarely would they speak of it in the groups.... I figured that the reason might be that these groups consisted of women who knew each other before they became group members ... blood relations ... and ... neighbors. ... What happened was that some women in a secret manner would give me a sign that they wanted to talk to me about something they could not tell in front of the group.

When necessary, these secret signs were then followed by individual therapy.

Apparently, it was easier for the health workers at Center A to single out victims of sexual violence, and they even had therapy groups with this particular group of war-trauma victims. Both centers, however, appear to have succeeded in attracting women victims of sexual violence through their female war-trauma focus, but the ways in which this approach succeeded in providing the victims with psychological therapy varied.

Framing sexual violence as one among many war traumas women suffered was also important for the health workers and their relationships with the larger communities. Some of the health workers at Center A were born and raised in the city in which the psychosocial center is located. They revealed that this was slightly problematic because their workplace was known as the rape center in the city. It was as though the stigma that was attached to the rape victims had spread to them. But when they could explain to their neighbors and families that they worked with women who were traumatized in different ways - in this way creating a unity among women suffering from different traumas during the war-they felt it was easier for them vis-á-vis outsiders.

What I have described above are ways in which the stigma attached to victims of sexual violence was managed within the psychosocial centers. By making vic- 
tims of sexual violence invisible, the centers removed the stigma that attached not only to the victims but also to the health workers and their other clients. Hiding the clients' war-rape experiences is largely explained as a pragmatic solution in response to a damaging identity. This way of arguing for and organizing psychosocial work shows that, despite the unexpected support that Bosniak victims of wartime sexual violence got from their religious leaders, the most prevalent way of conceptualizing victims of sexual violence was through stigmatization.

At Center B, where sexual violence was less visible in the therapeutic work than at Center A, those interviewed were clear about why women they suspected had been raped would not acknowledge this in group sessions or even in private conversations with the therapists. One concern could be the prospect of getting married in the future:

If they [potential partners] find out that they are with a girl who was raped, they would find it difficult. And if you think that you cannot live without a husband, and you have all those war trauma experiences, you need financial support, then you do not tell.

Another concern would be traditional male roles within families:

It [rape] was a weapon of war to destroy the family through the woman. ... A husband cannot see the woman in the same way as he did before, because of the traditional way of education and raising boys. People think that women could often prevent those acts.

\section{DISCOURSES OF POSTWAR VIOLENCE}

The postwar years have been-and continue to involve-a struggle to reconstruct and create normal lives in the midst of extraordinary destruction and social problems. A normal life for many Bosnians was described as a combination of the life they enjoyed in the prewar years and the current Western European mode of living. With an unemployment rate well over $50 \%,{ }^{8}$ young people fleeing the country to seek better futures elsewhere, and the scars and wounds of war still overshadowing the lives of most people, it is hard to patch together a normal life.

In the postwar period, the psychosocial centers have adapted their focus to address new social problems (see the Appendix for an outline of how they have developed). Sexual violence continues to be a primary concern, but the parameters

\footnotetext{
${ }^{8}$ The unemployment rate in Bosnia was estimated in 2002 to be between $40 \%$ and $80 \%$, depending on the area considered (Becirbasic \& Secic, 2002). The highest levels of unemployment are found in industrial areas where former communist-style industries have collapsed.
} 
for this particular form of violence have changed. The following section focuses on how the new postwar context brings out new discourses of sexual violence, and analyzes how these discourses are understood and described as linked to the war.

\section{Discourses of Transitions}

Domestic violence, drug abuse, high suicide rates, and prostitution are among the new areas of concern the health workers have to deal with in the aftermath of the war. The ways in which these problems are understood and talked about is twofold: On the one hand, there is a perception that sexual violence has increased as a result of the social unrest caused by the war, whereas on the other hand, there is the contrasting perception that more attention is given to these issues primarily because of all the aid workers who have come to the region and initiated psychosocial activities. In both cases, the war is seen as instrumental in making gendered violence a theme of public debate and concern. The question, then, is how and why the health workers argue that there has been an increase in sexual violence in postwar Bosnia and what implications this escalation has for their work?

The fact that the war was marked by a collapse in morality, which has created an increase in violence within Bosnian families, is a core argument within the sexual violence-on-the-increase line of thinking. One health worker explained:

I think war trauma made a lot of problems for domestic violence. ... We had domestic violence before the war, ... but it was much more of a secret ... very secret. ... For example, now our ... soldiers say that they are more aggressive .... They think it is better to be violent against women than against children. ... And women have also changed. ... During the war, they accepted to work and make some money for their families ... when the husbands came from the frontline they were lost and had many war traumas and nightmares and a lot of mixed troubles. ... But everything is connected with the war. ... I used to say that we had war trauma and postwar trauma, because many people after the war had trauma with money, how to survive ... how to get by ... and this is just a new problem in Bosnia.

This health worker focuses on the changing identities of demobilized male soldiers in Bosnia. They are, she says, more aggressive; they suffer from a range of war traumas and nightmares. In addition, they have come home to women who have taken up roles as breadwinners and caretakers of the family in ways normally afforded men. In other words, women have entered male arenas, which possibly adds to the aggression and frustration of many men. On top of all this come the economic frustration and material insecurity under which everyone lives. This frustration and insecurity is a classic postwar, gendered consequence. For many men, the distress of postconflict life, coupled with the changing roles of women, may lead to 
what Friedman (1992) described as a heightened male vulnerability. Feelings of helplessness and despair result from their inability to take care of their families and from having witnessed family members being raped, tortured, or killed. For some men, this vulnerability may lead to the use of domestic violence as a way of reestablishing control and power. For others, it may mean passivity and deep depression.

Another argument is that the symbolic value of women within Bosnian society changed after the war.

After the war came, we learned that people had been raped, and we had people in the streets who had been raped. ... After the war, people became less moral, and everything was allowed. ... This is a problem. ... And in our country, we completely changed our morals. ... Now it is normal to steal, and there is an increase in violence.

I think that the destruction of values was very important for people during the war. ... Girls were exposed to constant attack ... not only by the boys their own age, who also lost their values, ... but older men who experienced the war. We can understand the problems that they might have ... but they all go to solve their problems by placing the woman under them ... subordinate them.

In a thorough study of the roles of women in an ethnically mixed village in central Bosnia, Bringa (1995) argued that women in both Croat and Bosniak families were often seen as maintainers of family values and morals. The previous quotes suggest that as the war brought a collapse in normal values and morals, women increasingly became the targets of negative attention and violence. The values and morals they were seen to represent, according to Bringa, were distorted, and violence followed. This distortion means that the violence women experienced during the war did not end with the signing of the Dayton Peace Agreement in December 1995 but was simply moved to the private sphere as a result of changing male and female identities.

The health workers went on to point out that postwar violence, which they call domestic violence or civil trauma, is very different from war rape. It is more difficult to evoke the survivor identity for the victims in the postwar setting, because the perpetrator-victim relationship does not run along ethnic or political lines. In the postwar setting, a rape victim is first and foremost a female party injured by a male perpetrator. Indeed, rape is a form of violence in which the relationship between the individual men and women involved is brought into question. One health worker explained:

I think that the stigma for women raped during the peace period would be much stronger than towards the women raped during the war. ... During the 
war, we thought about our survival, and we thought about ourselves as a group against the enemy. ... But, in the peace, it is something else. ... We are not all equal. ... We have individual issues and lives. ... And the attitude towards individuals is different. ... This makes women alone in her trauma.

This development represents a shift toward normal perceptions of sexual violence in the Western world. In his introduction to the history of rape in France, Vigarello (2001) argued that the "crime is now glaringly visible, prominent as never before in police enquiries, court proceedings, newspaper articles and public concerns" ( $p$. 1) and goes on to say that this claim holds true for most Western societies. Acknowledging sexual violence as a problem shared with other European (and American) societies is therefore paradoxically regarded as a form of development toward a "normal" society. The following quote illustrates this point:

Now it is similar as in any Western society: the accusation against women about why she walked alone at night, why she wore a short skirt, and why she provoked the rape.

For the health workers, the challenge is how to transform their experiences as therapists with war traumas and sexual violence during the war years to adapt to situations involving peacetime violence against women. The pragmatic challenge is to adjust therapy models to fit more long-term abuse:

Rape in war was often once ... and rape in domestic violence is through many years by a close member of your family. ... In the war, it is one soldier, and perhaps even someone you do not even know, and this might make it easier for her. ... In domestic violence, the woman will ask why her father is doing this. ... In the war, it is just normal for the soldier, because they test different things. ... It is the most difficult for domestic violence.

Further, the health workers see a need to carry out more preventive measures and have increased and strengthened their information and outreach work (see the Appendix).

By arguing that there has been an increase in sexual violence against women in the postwar setting in Bosnia, the health workers describe new forms of masculinity and femininity. Men are seen to be more aggressive, whereas women are seen as symbols of changing values and morals. When a woman is subjected to sexual violence her mode of behavior, clothes, and attitudes are brought into question, which in many cases will be contrary to the ways in which a victim of a similar crime will be perceived during times of war, according to the health workers. During times of war, a woman's ethnic identity will come into play and will lessen her perceived degree of complicity in the acts. The health workers argue that what was consid- 
ered abnormal behavior during the war-that is, aberrant modes of morals and values-has become, to some extent, normal behavior in the postwar setting.

\section{Discourses of Traditions}

Sexual violence is also seen as inherent to the traditional patriarchal family structure in Bosnia. The perceived increase, goes the argument, is simply the result of more attention devoted to this particular kind of violence. Although statistical measures might be able to evaluate this line of argument, such statistics do not exist. In any case, the reason that more attention is being paid in Bosnia today is because the war brought a new awareness about gender-related violence:

In the beginning, we started to work with women victims of war, and we started talking openly about the violence of war, and we were the first to talk about violence against women ... probably because we had so many journalists who came and wrote about the violence. Women who experienced domestic violence probably thought that people here would listen. ... I think that was the main reason why women started to come here. It was the trust during the war, and we were the first organization who openly started to talk about this.

Another health worker explained:

I know that there were rapes in Bosnia before. ... Whether the number of rapes have increased or decreased I do not know. ... It is maybe the point that we are more aware of the rape as a crime .... Before, the woman would have to keep her mouth shut.... The background story is that she caused it in this way or another ... by wearing specific clothes. ... Now, more and more people think that she should be allowed to wear what she wants.... And now we talk about the issue for the first time in the history of this country ... and many women are now aware that no one has the right to rape them. ... Most are aware that they should talk about it and make it visible.

Yet, despite the optimism of this particular health worker, another health worker explained the difficulties they face when educating women about the issue of domestic violence, especially in what is considered traditional-that is, strongly patriarchal-families:

All of us Serbs, Catholics, and Bosniaks ... all of them they have the same way of thinking ... the same tradition. ... If you have a daughter, the purpose for that girl is to get married ... deliver babies ... cook and work in the field $\ldots$ and it is hard work ... and to take care of her husband ... and to wash his 
legs and to be very nice to her husband when he beats her.... And some of them would talk to each other and say that my husband is very nice, he only beats me once a month, or only once a week ... because their fathers ... they are taught to live like that $\ldots$ because he was beating their mother ... and that is normal.

Because violence against women also is seen as an integral part of traditional patriarchal family structures in Bosnia, the health workers have taken it on themselves to inform the larger public and change these perceptions. This has taken the form of extensive, professionalized collection, analysis, and dissemination of statistical information about their work and the prevalence of different problems. Furthermore, they often use the local media to promote their activities, while also focusing on women's rights in more general terms. In addition, both centers are parts of different networks-local NGOs and women's NGOs in Bosnia, as well as international networks for women's organizations. These efforts enable them to disseminate their insights and experiences more and more widely.

This transformation in information and activities, however, also has a down side. The increased focus on issues relating to women's rights in Bosnia has led to reduced contributions from foreign donors, which are primarily interested in war-related problems. It is therefore clear that the more the health workers make a connection between current problems faced by women and the war-that is, the more clearly they can argue that sexual violence during the war has been transformed into an increase in sexual violence in the postwar aftermath-the more likely they are to get attention from the internationals. On the positive side, however, these information efforts contribute to keeping sexual violence part of a public discourse in Bosnia. There are now SOS hotlines, established in the immediate postwar years, where people can call for legal and psychosocial assistance when they have experienced different kinds of violence, including sexual violence. To make their work known, the workers at the centers have publicized these SOS hotlines in the local communities, thereby acknowledging that sexual violence is a problem of public concern for which there are legal and psychosocial implications.

This line of argument shows that sexual violence is a grave problem in Bosnia today. However, the conceptualization of masculinity and femininity here is different from that found within the transition arguments. As the previous quote shows, the deeply rooted patriarchal structures of Bosnian families are seen as the prime reason for sexual violence. For a man to have sex with his wife when he wants is regarded as his right. Also, the notion of rape among married couples is perceived as a contradiction in terms. For many of the health workers, this kind of male-female relationship is viewed as not only traditional but also highly rural. The fact that the demography of Bosnia has changed drastically during the war years-many rural inhabitants have been forced to move to urban centers and live in refugee settlements-has also changed perceptions about what are considered normal relationships between men and women. 


\section{CONCLUSIONS}

Returning to the initial assumptions of this article, we are faced with a central question: What have the health workers' reflections taught us about sexual violence in war in general and about the impact of sexual violence during the Bosnian war in particular?

First and foremost, this analysis shows that it is possible to study sexual violence in war in an empirical, qualitative manner, despite the fact that many victims of this form of violence remain silent. Questions about the ethics of such research can be answered by noting that it would be, in fact, unethical to not investigate this theme simply because it would be difficult. By not asking questions and trying to understand how sexual violence in war impacts victims and the societies and families to which they belong, yet another assault is perpetrated against them because their ordeals are made invisible. It was crucial to find a way to understand the impact of sexual violence during the Bosnian war without posing unethical questions to victims who did not choose to speak. The health workers provided valuable insights because they, as a group, speak as liaisons between victims, and potential victims, of sexual violence and their local communities. One conclusion, therefore, is that to study the impact of sexual violence in war, it is crucial that we identify people who have contact with the victims in the local community. These liaisons are best situated to explain the cultural implications of sexual violence in the given conflict setting.

Second, this study has shown that the impact of sexual violence in war varies according to context. The context of war brought a discourse in which sexual violence was defined as war violence. This discursive construction made it possible for both the women subjected to sexual violence and the health workers to be positioned as victims, albeit in different ways. Through this common identity, the health workers became motivated to work with women who had suffered from different kinds of war trauma, including sexual violence. To keep on with their work, however, it was important for the health workers to maintain some distance from their clients and situate themselves as professionals. This was made possible through education on war traumas and trauma psychology. In turn, this education enabled the health workers to talk about sexual violence with clients and others in ways they had not done before.

By naming and identifying sexual violence and its victims, the health workers were able to situate the rape victims and their experiences in different ways. On the one hand, the victims were seen as war survivors, in line with the fatwa issued by Bosnian Islamic leaders. The ways in which sexual violence became politicized took, to some degree, the stigma away from the female victim. Her ethnicity determined whether she was "eligible" for attack. By situating the sexual-violence victims as ethnic subjects, a sense of unity was created between men and women within the same ethnic group. For the local health workers, this unity created a basis for therapy because the victims of sexual violence received support and under- 
standing from their families and communities. On the other hand, the most prevalent identity for the victims of sexual violence was as stigmatized women, which also had implications for the health workers. They risked being "smitten" by the same stigma attached to the victims. As a result, the psychosocial centers became multifaceted in outlook. They provided an array of services to their clients and addressed different kinds of war traumas such as rape, torture, and loss of homes and family members.

In the postwar context, sexual violence and its victims are situated differently. The political context shifted and sexual violence became more a question of male and female power relations, and less a question of ethnicity. It is through the health workers' discussions about rape in postwar Bosnia that we see the contours of the long-term sociopolitical implications of war rape. On the one hand, the health workers describe an increase in sexual violence in the postconflict settings, which they attribute to a collapse in values and morals during the war years. The use of sexual violence during the war is seen as one manifestation of such a collapse. This analysis suggests a hegemonic gender relationship comprised of aggressive men and subordinate women. On the other hand, another line of argument claims that the hegemonic relationship between the genders has not been altered. Rather, it is awareness about women's rights that has increased, owing to the huge focus on sexual violence against women during the war. For the health workers, both lines of argument have led to different changes in their work methods (more focus on long-term abuse and family therapy), choice of clients (more focus on the role of men in families and adolescent behavior), and outreach target groups (more focus on reaching boys and girls of school age).

Does this article represent the truth about the impact of sexual violence during the Bosnian war? Obviously, it does not. It does, however, present one avenue to understanding and shows that where other methods might fail due to unreliable or nonexistent data, discourse analysis is a useful first step in a comprehensive analysis of a complex phenomenon. Sexual violence is not simply sexual violence that happens to occur during the course of a war, but it is a distinct form of sexual violence that might require, as has been shown in this article, unique therapy methods from health workers. These therapy methods must balance between the assumptions that there are universal effects of sexual violence, which cut across various contexts, and cultural relativism, which assumes the opposite. Close cooperation between international and local health workers is one way of managing this challenge. This insight suggests that both aid workers and policymakers in conflict areas must also balance their efforts in postconflict settings to assist the victims in a nonstigmatizing fashion. Carefully analyzing the gendered pre- and postwar culture, along with the ways in which gender relations become politicized during the conflict, is therefore crucial to meet the needs of the victims most effectively. Finally, it is crucial to conduct more empirical research to compare findings across cultures. Increased empirical knowledge should bring us closer to an accurate defi- 
nition of war rape, a definition that clearly sets these acts apart both from other forms of violence during times of war as well as from rape in postwar settings.

\section{ACKNOWLEDGMENTS}

This article was written while I held a Fulbright Scholarship at the Institute for Slavic, East European and Eurasian Studies (ISEEES) at University of California, Berkeley (2002-2003). ISEEES Director Barbara Voytek deserves special thanks for having facilitated my research stay at UC Berkeley. Earlier versions of the article have been presented at Scripps College, the Center for International Studies at the University of Southern California, and at the conference "Power and Power Relations in East European Politics and Societies," organized by ISEEES in 2002. Regrettably, I have had to conceal the identities of the informants and the psychosocial centers in this study. Had it been possible, you all should have been named and thanked in full. I would like to thank a number of people for their comments prior to or during these presentations. In alphabetical order, these thanks go out to George Breslauer of UC Berkeley; Hjørdis Kaul of NTNU, Norway; Iver B. Neumann of NUPI, Norway; Berit Schei of NTNU, Norway; John Erik Riley; Dan Smith of PRIO, Norway; and Marguerite R. Waller of UCLA.

\section{BIOGRAPHICAL NOTE}

Inger Skjelsbæk is a researcher at the International Peace Research Institute, Oslo (PRIO). She has an extensive publication record in the field of gender, peace, and conflict. She is now concluding her doctoral studies in social/political psychology at the Faculty of Social Sciences and Technology Management at the Norwegian University for Science and Technology (NTNU).

\section{REFERENCES}

Allen, B. (1996). Rape warfare: The hidden genocide in Bosnia-Herzegovina and Croatia. Minneapolis: University of Minnesota Press.

Becirbasic, B., \& Secic, D. (2002, November 18). Invisible casualties of war. Balkan Investigative Report, 383. Available from http://www.iwpr.net/index.pl?archive/bcr3/bcr3_200211_383_4_eng.txt

Bernard, C. (1994). Rape as terror: The case of Bosnia. Terrorism and Political Violence, 6, $29-43$.

Bringa, T. (1995). Being Muslim the Bosnian way. Princeton, NJ: Princeton University Press.

Brownmiller, S. (1994). Making female bodies the battlefield. In A. Stiglmayer (Ed.), Mass rape: The war against women in Bosnia-Herzegovina (pp. 180-182). Lincoln: University of Nebraska Press. Card, C. (1996). Rape as a weapon of war. Hypatia, 11(4), 5-18. 
Friedman, A. R. (1992). Rape and domestic violence: The experience of refugee women. Women and Therapy, 13(1-2), 65-78.

Gal, S., \& Kligman, G. (2000). The politics of gender after socialism. Princeton, NJ: Princeton University Press.

Gergen, K. J. (1999). An invitation to social construction. London: Sage.

Holbrooke, R. (1999). To end a war. New York: Modern Library.

Human Rights Watch. (1996). Shattered lives: Sexual violence during the Rwandan genocide and its aftermath. New York: Author.

Jones, A. (1994). Gender and ethnic conflict in ex-Yugoslavia. Ethnic and Racial Studies, 17, 114-134.

Jordan, M. J. (1995). Rape as warfare. Transition, 1(20), 20-21.

Jørgensen, M. W., \& Phillips, L. (1999). Diskursanalyse som teori og metode [Discourse analysis as theory and method]. Roskilde, Denmark: Roskilde Universitetsforlag.

Kaplan, R. D. (1993) Balkan ghosts: A journey through history. New York: St. Martin's.

MacKinnon, C. (1994). Turning rape into pornography: Postmodern genocide. In A. Stiglmayer (Ed.), Mass rape: The war against women in Bosnia-Herzegovina (pp. 73-81). Lincoln: University of Nebraska Press.

Potter, J., \& Wetherell, M. (1987). Discourse and social psychology. London: Sage.

Rape as a weapon of war. (1993, August). Refugees, pp. 42-44.

Salzman, T. A. (1998). Rape camps as a means of ethnic cleansing: Religious, cultural and ethical responses to rape victims in the Former Yugoslavia. Human Rights Quarterly, 20, 348-378.

Seifert, R. (1994). War and rape: A preliminary analysis. In A. Stiglmayer (Ed.), Mass rape: The war against women in Bosnia-Herzegovina (pp. 54-72). Lincoln: University of Nebraska Press.

Stiglmayer, A. (Ed.). (1994). Mass rape: The war against women in Bosnia-Herzegovina. Lincoln: University of Nebraska Press.

Thomas, D. Q., \& Ralph, R. E. (1994). Rape in war: Challenging the tradition of impunity. Sais Review, 14, 81-99.

Vigarello, G. (2001). A history of rape: Sexual violence in France from the 16th to the 20th Century. Cambridge, England: Polity.

Vranic, S. (1996). Breaking the wall of silence: The voices of raped in Bosnia. Zagreb, Croatia: Anti Barbarus.

West, R. (1977). Black lamb and grey falcon: A journey through Yugoslavia. London: Macmillan. (Original work published 1942)

Wetherell, M. (2001). Editor's introduction. In M. Wetherell, S. Taylor, \& S. J. Yates (Eds.), Discourse theory and practice: A reader (pp. 1-9). London: Sage.

Zarkov, D. (1997). War rapes in Bosnia: On masculinity, femininity and power of the rape victim identity. Tijdschrift voor Criminologie, 39, 140-151. 


\section{APPENDIX: The Psychosocial Centers ${ }^{9}$}

The establishment of both of the psychosocial centers followed similar patterns. Local women came together, motivated by a wish to help IDPs who were coming to the hometowns of the health workers. The formal establishment of the centers came about when foreign individuals and organizations arrived seeking local partners with whom they could establish psychosocial assistance specifically aimed at Bosnian women. These international humanitarian workers had been appalled by news accounts and reports of human rights violations in general, and the situation of women who had been subjected to mass rapes in particular. Collaborative efforts between internationals and locals led to the official opening of Center A in early 1993, and the opening of Center B in early 1994, although in both cases unofficial activities had been going on since 1992. In principle, both centers were multiethnic in outlook and staff, but in reality both staff and clients were predominantly Bosniak.

Center A, where I interviewed 14 health workers, was established to assist war-raped women and their families. The center offered medical, therapeutic, legal, and social help to its clients free of charge. Although their primary goal was to assist raped women, it was essential to all concerned that the center not become known as "the rape center." Consequently, they welcomed women suffering from a vast range of war traumas, along with their families. Center A was comprised of several houses that served different functions such as a day clinic, living accommodation, and an information center. Some clients lived at the center for varying amounts of time, whereas others only visited during the day. In the beginning, potential clients were identified and approached during visits to collective centers in the town and its immediate vicinity. The health workers presented the work of the psychosocial center to encourage women who needed help to contact them. For the most part, employees work full-time and describe their work as being more than just a job. Their work and commitment has offered them safety, education, salaries, and even in some cases food during difficult times. The center has close contact and a degree of cooperation with local police, health authorities, and social services. In the years since the war, this cooperation has grown closer. The center, however, has struggled to stay afloat in the postconflict years because it did not attract the same level of engagement from international donors—on which they were entirely dependent.

Center B, where I interviewed 9 health workers, had a broader approach to war trauma. Unlike Center A, it did not single out victims of war rape in particular but

\footnotetext{
${ }^{9}$ The health workers deserve special thanks for having made the most important contribution to this study. Because the interviewees are anonymous, neither they nor the psychosocial centers can be identified. Their support and enthusiasm have been invaluable to me and I am deeply indebted to them.
} 
rather included this particular experience within a wider framework. It was established as a day center for women and children, offering therapy, legal assistance, and social help. Here, too, all services were provided free of charge. There was, however, a very different employment policy in Center B. Health workers were employed for no more than half-time for two reasons. First, it was important for the founders not to "steal" employees from their other jobs; they hoped that local staff would find ways to combine work with the center and any previous employment. Second, that the employees had other jobs in the local community increased the possibility of identifying traumatized people who might be in need of help. As with Center A, the health workers carried out - and continue to carry out-a great deal of outreach work. They were able to reach people not only in collective centers, but in schools, hospitals, and other places in the local community where the health workers had their primary work. Although Center B has been a center for women and children, it has also provided therapy for men, albeit to a limited extent, and has focused considerable effort on adolescents. In addition to in-house work, the health workers also followed up group therapy in numerous collective centers in the vicinity of the town.

In the postwar setting, both centers focus on similar themes, such as domestic violence, suicide, drug abuse, and prostitution, and they have changed their focus from war trauma to postwar trauma (or "civil trauma," as many of them call it). Politically, they have taken on slightly different roles in their local communities: one center has established an information department for disseminating information about its work, as well as on women's rights in the larger community, whereas the other center has expanded its activities with more outreach work to new groups, such as adolescents, children, and men, and provides help with a vast array of psychosocial needs.

The majority of the health workers remained committed to their work throughout the war and postwar years, despite periods of extreme stress, uncertainty, and burnout. 